\title{
Хронотоп лечебного ритуала: на примере народноветеринарных практик белорусов
}

\section{Александра Шрубок}

Центр исследований белорусской культуры, языка и литературы Национальной академии наук Беларуси aliaksandra.shrubok@gmail.com

Аннотация: В статье приводится анализ пространственных и временных особенностей белорусских ритуальных практик охраны и восстановления здоровья скота. Выделение особых сакрально маркированных единиц времени и пространства, наделение их определенными семиотическими и культурными функциями предопределяется традиционными мифопоэтическими представлениями. Наибольшее значение в хронотопе лечебного ритуала играют "пограничные" точки, которые, согласно с народным представлениям, выполняют функции медиаторов. Приуроченные к календарным праздникам профилактические мероприятия должны были закрепить результат магического воздействия на здоровье скота и распространить его на последующий период, в то время как приуроченные к восходу или закату солнца окказиональные ритуалы, равно как и задействованные сакрально маркированные локусы, стремились “перевести" недуг из сферы “своего” в сферу “чужого”, восстанавливая и поддерживая тем самым принятый в культуре порядок вещей.

Ключевые слова: ритуал, хронотоп, народная ветеринария, мифопоэтические представления 


\section{Введение}

В традиционной культуре представления о времени и пространстве - основные категории модели мира - являются неотъемлемой частью мировоззрения. Организация и исполнение магического ритуала строго подчиняются установленным правилам, которые формируются под влиянием определенных представлений о времени и пространстве. В данном случае, опираясь на богатый фольклорно-этнографический материал народноветеринарных практик белорусов, делается попытка определить специфику пространство-временных характеристик лечебного ритуала.

\section{Хронологические рамки лечебного ритуала}

Ритуальное время, воспринимаемое как разрыв обычного, земного времени, прорыв во время вечное, сакральное, - один из главных параметров структуры ритуала (Толстая 1995: 451). Время в лечебных ритуалах и связанных с ними верованиях предстает как «условное, непрерывное, замкнутое, насыщенное сакрально выделенными моментами» (Валодзіна 2009: 370). Выделение же отдельных сакрально маркированных единиц и наделение их определенными семиотическими и культурными фрункциями предопределяется традиционными представлениями. Так, лечебный ритуал может ориентироваться на природные явления (прежде всего, солнечный и лунный циклы) и социокультурные события - праздники, дни недели. Ориентация на определенные праздники, при этом, более характерна для профилактических ритуалов, цель которых повлиять на здоровье скота в будущем.

Образ луны в традиционном врачевании наделяется теми или иными качествами в зависимости от своей фразы. Так, новолуние связано с более положительными коннотациями, чем последняя четверть, или т.н. «старая луна». Отнесение же определенного лечебного ритуала к конкретной фразе луны строго обусловлено представлениями о виде болезни или целью ритуала. Например, кастрацию животных, как отмечал Ч. Петкевич, белорусские крестьяне приурочивали именно к последней чет- 
верти лунного цикла («на сходніх днях»), поскольку проведение этой операции в другое время, в частности, в новолуние («на маладзіку»), согласно с народным представлениям, вызывало осложнения ("Як злягчаць скаціну на маладзіку, то вельлі доўга будзе гаіциа, то шчэ і чэрві завядуциа») (Пяткевіч 2004: 394).

Дневным регулятором лечебных ритуалов служит солнце. Абсолютное большинство рекомендаций носителей традиции приурочивается к восходу или закату солнца. Например, см. комментарии к заговорам: «На заре три разьь, на хлеби, чистол, аржанол; сольлю посьюпаюць и даць изьесьци» (Романов 1891: 103-104); «Тройчи, на зарах; по животу гладзиць рукою» (Романов 1891: 124). В XIX в. М. Дмитриев приводит следующее описание ритуальных способов избавления больного животного от червей: «а) берут шерсть той скотины, которая имеет червей, и перед закатом солнца, когда оно на половине, и лучами освещает дом или какое-нибудь строение, высверливают дырочку в бревне, под лучами солнца, кладут в нее шерсть эту и вколачивают туда осиновый клинок, говоря при этом, чтобы у такой-то скотины пропали черви; б) также перед закатом солнца идут в поле, где растет Дзиванна, наклоняют ее к земле, говоря, что ее до тех пор не отклонят прямо, пока у такой-то скотины не пропадут черви» (Дмитриев 1869: 263). Тут очевидно актуализируются представления о пограничном статусе времени восхода и заката солнца, времени между позитивно маркированным днем и ночью, которая ассоциируется в традиционной картине мира с враждебным временем, принадлежащим не к человеческой, а инфернальной сфере (Толстая 1995: 450). Границы имеют наибольшее значение в оценке времени, что справедливо и для пространственного кода, как мы увидим далее. Кроме того, само явление заката солнца традиционно ассоциируется в мифопоэтическом сознании с его смертью, поэтому соотнесение лечебного ритуала с этим временным отрезком имеет целью низвести болезнь в небытие.

Как отметила Т. Володина, «традиционное отнесение ночи, полночи, луны, заката солнца к знаку “чужого” в противовес утру, полдню и т.д. как представителям “своего” в народномедицинских ритуалах не выступает в категоричной форме, скорее это пограничные точки, равнозначные в своем открывании канала воздействия на болезнь или контактирования с ней» (Валодзіна 2009: 371). Разумеется, данное обстоятельство целиком 
справедливо и для народноветеринарных ритуалов, поскольку они опираются на общую логику с народномедицинскими. При этом некоторые аксиологические оценки времени в традиционном врачевании все же существуют. Это проявляется в существовании представлений о т.н. плохой («благой») минуте: «Болезнь случается, когда человек что-нибудь подумает в плохое время, "калі трапіць у злую минуту, иі планету", а такая минута бывает каждый день три раза - утром, в полдень и вечером. Проклятие, произнесенное кем-нибудь в такую минуту, также сбывается» (Wereńko 1896: 213).

Полдень в традиционном мировоззрении - маркированная граница в дневном цикле, “временной “стык”, “поворот” времени, когда старый период уже закончился, а новый еще не начался, момент, когда время как будто не существует, и открыта граница между земным и потусторонним миром, спрятанным от человека в обычное время» (Левкиевская 2009а: 131). Восприятие полдня как кратковременного периода потенциальной интервенции "нечистой силы» обусловило исключение этого временного отрезка из хронотопа лечебного ритуала. См., например, следующий комментарий к заговору: «Бращь пасвяионую ваду і на руку ліиь і па спіне і па хвасту. Перад этылм пачьттаць тры разы Отча наш. У абед нельзя. Ілі да 9-10 утра і после 5 вечара» (ТМКБ 2013: 976).

Противоположный полдню временной период - полночь воспринимался как «довремя» или "не-время», период наивысшей активности нечистой силы (Раденкович 2005: 73, 76). Считалось, что в этот отрезок суточного цикла время останавливается, поэтому полночь принадлежит иномирию, наделенному свойствами отдавать свои целебные качества: «Некоторые деды уверены, что вода останавливается в полночь на три минуты в своем течении, потому люди “с прихомотями”, смелые колдуны и колдуньи "отправляются в глушь к речке, берут воду и пользуются ею при лечении от суроц”» (Добровольский 1914: 656). Подобное верование зафиксировал в конце XIX в. и Ф. Веренько, который отмечал, что вода, зачерпнутая из реки в полнолуние, в самую полночь, в то время, когда «вода засыпает», считалась в народе профилактическим средством, помогающим сразу от всех болезней (Wereńko 1896: 109).

Ритуалом, концентрирующим в своем исполнении магические возможности времени, можно считать ритуал создания 
«абыдзённіка», который осуществлялся во время серьезной опасности, угрожающей благополучию всей деревенской общины, - эпидемии или эпизоотии. Ритуал заключался в том, что во время мора деревенские женщины собирались вместе и должны были в течение дня (отсюда название: «абыдзённы», что значит однодневный), или - в течение одной ночи, до восхода солнца, напрясть нитей и выткать из них полотно. Дальнейшие действия с полотном варьируются в зависимости от местности: его могли отнести в церковь (Дмитриев 1869: 264; Романов 1912: 316); вешали на специально установленный с этой целью деревянный крест на окраине деревни или на дороге (Крачковский 1869: 197-198; Шейн 1902: 294); часто через расстеленное полотно перегоняли стада и т.д. (См. Журавлев 1994: 120-121). Подобный ритуал могли исполнять и в отдельных хозяйствах при лечении мастита: «Калі у каровы прападала малако, ёй пад ногі клалі рушнік, сатканы за адзін дзень» ${ }^{1}$.

Лечебные ритуалы в основном имеют окказиональный характер и не приурочены к определенным календарным рамкам, поскольку реальное заболевание обычно случается непредсказуемо. Тем не менее, многочисленные профилактические мероприятия, направленные на предупреждение болезней и укрепление здоровья скота, были приурочены к определенным точкам годового цикла. Среди таких точек в народном календаре белорусов можно выделить те, что непосредственно связаны с животноводческой деятельностью (дни св. Юрия (Георгия), св. Флора и Лавра, св. Власия и др.), а также те, которые не имеют с ней непосредственной связи (Коляды, Сретение, Пасха, Великий (Чистый) четверг, Купала и др.). Объединяет же перечисленные праздники то, что роль семантической доминанты, предопределяющей проведение профилактических ритуальных мероприятий именно в эти дни, играет идея чистоты и обновления (Валодзіна 2009: 373). Приуроченные к этим дням профилактические и продуцирующие ритуалы должны были «зафиксировать» новообретенные в ходе их исполнения качества и распространить их, санкционировать на весь последующий период (Байбурин 1993: 123-124), пока новый ритуал не запустит еще один цикл.

Среди календарных обрядов, связанных с животноводческой деятельностью, центральное место принадлежит празднованию дня св. Юрия (23 апреля), во время которого осуществлялся 


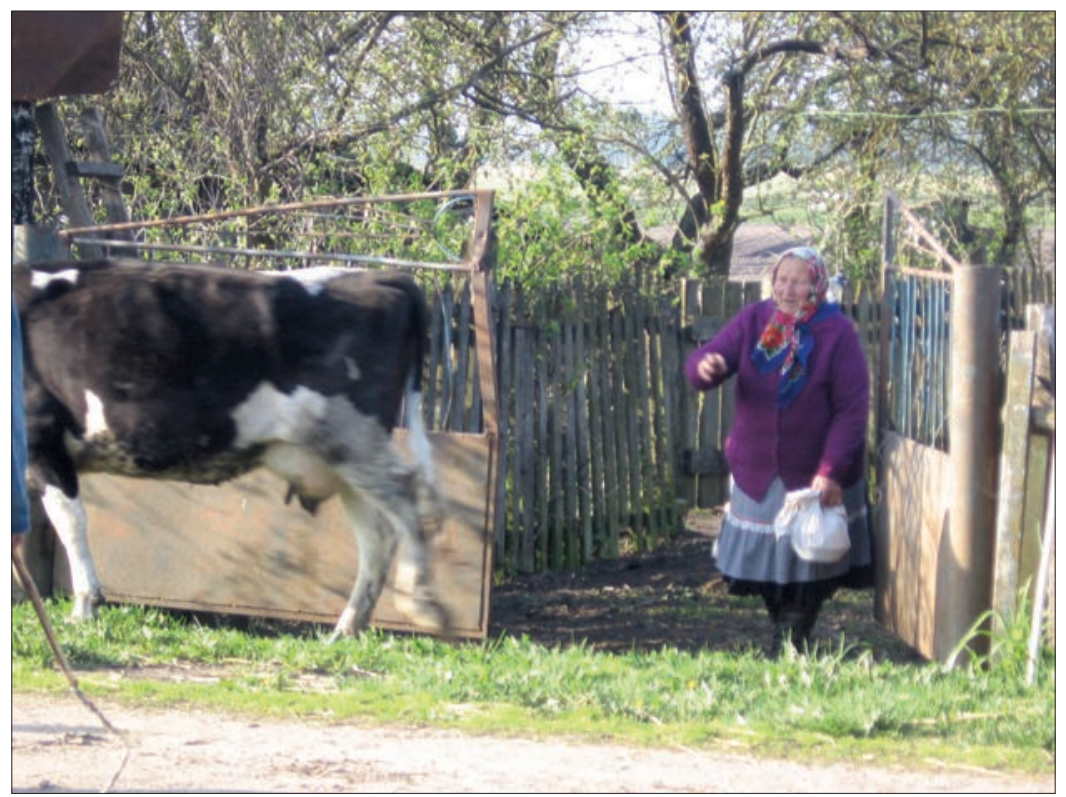

Первый выгон вербочкой в поле. Любанский район Минской обл. Фото С. Выскварки, 2014 г.

ритуал первого выгона стада в поле. В этот день в разных регионах Беларуси в храмах читаются молитвы св. Юрию (Георгию), осуществляются обрядовые обходы стада, хозяева стараются почтить пастухов, устраиваются праздничные ужины и т.д. Однако определяющий момент всего обряда - сам переход животного через порог хлева или ворот усадьбы, который осознавался представителями традиционной культуры символическим воплощением перехода между освоенным, «своим» пространством и потенциально враждебным «чужим» внешним миром. Для того чтобы сделать этот переход безопасным, обеспечить благополучный выгон на весь дальнейший сезон, поспособствовать молочности, плодовитости и доброму здоровью скота, хозяева использовали разного рода апотропеи, сопровождали выгон определенными ритуальными действиями и вербальными фрормулами (см. Шрубок 2015). Например, «патрэбна пакласиі путьь, залкнуць залкол, палажыць іх у варотах і перагнаць 


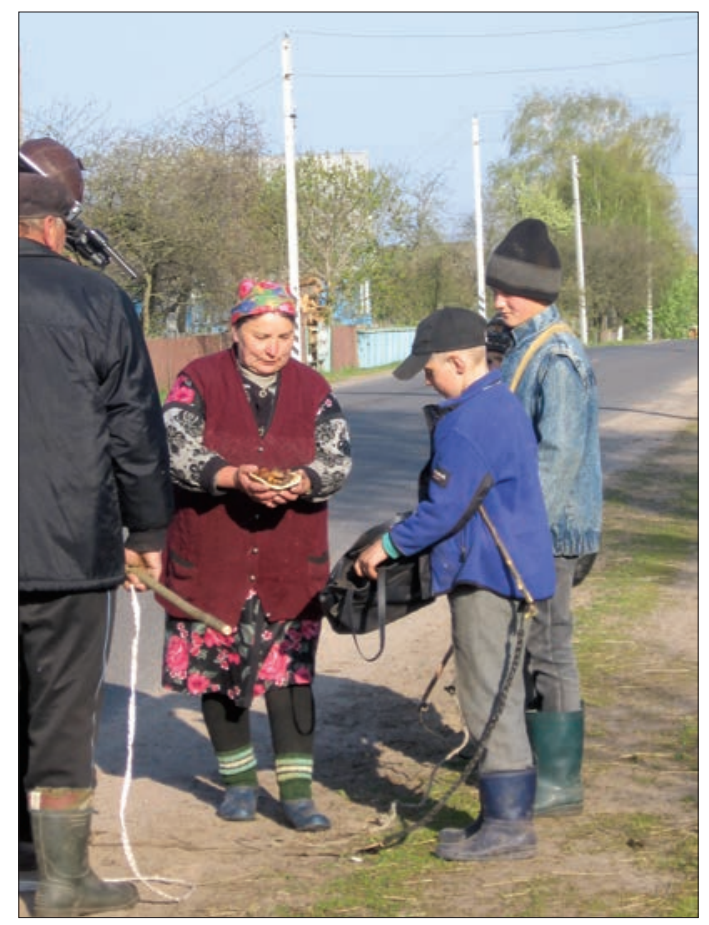

Первый выгон скота. Пастушки собирают угощение. Любанский район Минской обл. Фото С. Выскварки, 2014 г.

праз іх карову, пры гэтылм кажучы: "Выганяю сваю скацінку (іля), тынал яе укрываю, а змею і змяісе цэпал глаза засиілаю. Як таго гэтага злею $і$ змяісі не разарваці, так у етай кароўкі малака, шарсиінкі не уззиі"»".

Колядный комплекс с точки зрения лечебной и апотропеической магии характеризуется наличием широкого блока предписаний и табу. Так, чтобы скот в течение года оставался здоров, утром в первый день Коляд примешивали в корм солому, которой был застлан праздничный стол (Federowski 1897: 345); в Пинском районе существовал обычай в день Нового года сжигать старые веники, чтобы коровы хорошо телились и давали много молока (Булгаковский 1890: 182). В этот праздничный период стремились также не нарушать определенные 
запреты: «Між Каляд ні можно круп да кіслаі стравы кідаць, бо у жывіны заведзецьсе гэта брыда - чэрві»; «Паліж Каляд ні можно клубка звіваць, бо гоўца будуць круиіцьсе»; «Паліж Каляд ні ложно трасиі клоча, бо як сьвіня апаросіцьсе, то будуиь парасятка трасьиісе. Треба гэтаго сьцерагчьсе, бо гэто дазнана реч» (Federowski 1897: 345, 349, 352).

В профилактических, а также продуцирующих целях в день празднования Крещения в корм скоту добавляли засушенные и растертые блины, которые специально для этого хранили с Коляд (Романов 1912: 301). Освященной в храме на Крещение водой окропляли домашних животных, на дверях сараев рисовали мелом кресты, чтоб туда в дальнейшем не могла проникнуть «нечистая сила» (Романов 1911: 41).

В Чистый Четверг, чтобы обеспечить хорошее здоровье скоту, особенно лошадям, животных обмывали водой до восхода солнца, обкатывали яйцом: «Чтоб конь не спадал с тела и был бы гладким, нужно вести его на водопой в Чистый Четверг до солнца. Тут перво-наперво нужно облить его водой, а потом покатать по нему первое снесенное курицей яйцо, и это последнее отдать потом нищему или какому-нибудь “калядоўшчыку”» (Никифоровский 1897: 143) (См. также Wereńko 1896: 218; Шейн 1902: 164; Романов 1912: 300).

Множество предписаний выработала традиция и в отношении Купалья (день св. Яна/Ивана), которое, согласно народным представлениям, считалось одним из наиболее опасных периодов в году: «Ночь с 23 на 24 июня, по народному мнению, полна ведьмами. Верят, что ведьмы всю ночь летают и отбирают молоко. 24 июня утром, до восхода солнца, ведьма идет с черной тряпкой в поле и со ржи собирает на тряпку росу. С чьей ржи собрана роса, у того не будет у коров молока» (Романов 1911: 75; см. также Шейн 1902: 263). В этот день крестьяне избегали выгонять свою корову на пастбище первой, поскольку считалось, что ведьма обязательно сглазит это животное: «На Ивана Купала ведьма до восхода солнца тягает скатерть по росе с той целью, чтобы “отобрать” молоко у той коровы, которая раньше других выйдет в поле, поэтому крестьяне в этот день стремятся позже выгонять скотину» (Шейн 1902: 496-497). Еще один запрет касался займов: «На Купалле нікалу нічога не давайце з хаты. Нікалу не давайце! У ляне ж карова прапала...» (ПЭЗ 2011: 21; см. также Шейн 1902: 263). Разумеется, в традиции 
был разработан и целый комплекс контрмер, направленных на предохранение скота от сглаза и других чар: «На Купалу вянкі вешалі каровал, пастух вешаеиь вянкі, напляце на пасие, усіл каровал павешаець $і$ гоніць. Кожны хазяін далжон ялу што-та даць: иі яйкі, иі што, иі рубль. Гэта, каб не сурочьлі. Гәта было. Гәта усё полняць: хто жыу $і$ дзяржаў кароў, што nастух гэта рабіуу» (ПЭЗ 2011: 20); «До Ивана стаў деда воротали хлева у ходу; посли Ивана выши деда поклади: никакая дрянь ня будеть сдаватиа у хлеви и к скоту чиплятиа» (Добровольский 1914: 838).

К Купалью были приурочены и некоторые продуцирующие ритуалы. Например, «На Ивана тые разы росу збираюиь и говоряиь слова: "Человек Оврал, все поле зораў, а жонка Сошвея это зелье содзила, а Божа Маци росою поливала. Хто будзе эту росу избираць, толу будзе ему Бох пологаць”. Росу корове збирае до сониа. Да уже дающь корове рано ту росу, шоб молоко було: “Як ета роса прибувае, шоб так у моёй корове молоко прибувало” (Полесские заговоры 2003: № 860).

Праздничные дни играли существенную роль и в приготовлении разного рода апотропеев и лекарств, поскольку именно в эти дни, согласно народным представлениям, актуализировались связи между повседневным миром и миром сакральным. Так, во время Сретенья крестьяне делали и освящали в храме свечи («гралніцьљ), которыми впоследствии выжигали изображения креста на домах и хозяйственных постройках, а также шерсть на голове животных, подвешивая затем свечи в хлеве. Согласно распространенному верованию, оставленные в хлеве «гралніцы» должны были защищать от ведьм, которые отбирают у коров молоко (Берман 1873: 19-20; Шейн 1902: 156-157). Эфективным средством при лечении вздутия у коров считалась соль, которая лежала под скатерью во время праздничного застолья в дни поминовения предков («Дзяды») (Wereńko 1896: 224). Целебные свойства приписываются также веточке вербы, освященной в храме в Вербное воскресенье, «четверговой» соли и т.п. Например, «Соллю во гэтай свянсионай на Чысты чацвер, тожа як у иэркаў хадзілі, свенцілі, гэту асвяшчалі сольку. Тады соллю. Карове давалі на хлеб, так $і$ у ваду».

Несмотря на то, что каждый праздник оказал свое влияние на семантику лечебных практик, приуроченных к ним, все они объединяются идеей начала, когда, согласно традиционным 


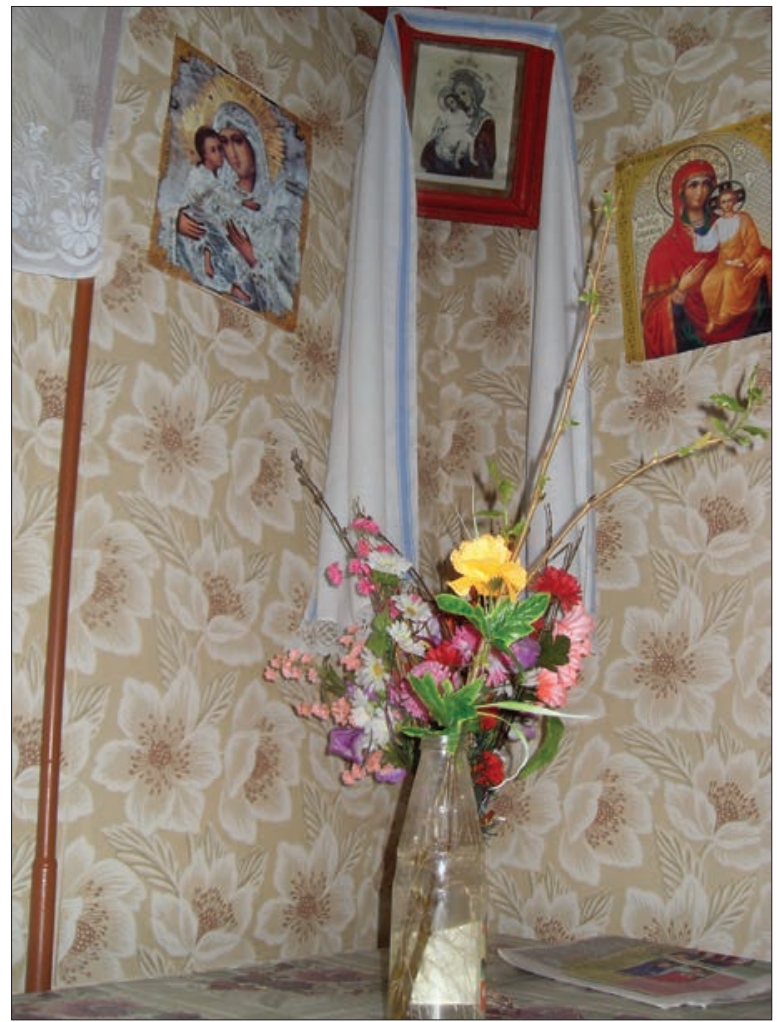

Верба, которой выгоняли скот в поле. Смолевичский район Минской обл. Фото Т. Кухаронак.

представлениям, приобретенные в это время качества и характеристики должны проявляться в течение всего года. Кроме того, включенность лечебных мероприятий в структуру календарного праздника предопределяется таким важным обстоятельством, как символическая изоморфность праздничного времени и больного существа с их определяющим статусом перехода: для больного - от болезни к здоровому состоянию или укреплению здоровья, а для праздника - от одного периода (сезона/поры года) к другому (Валодзіна 2009: 374). 


\section{Пространственный код лечебного ритуала}

Пространство не только моделирует структуру лечебных магических практик, но и часто выступает как главный действующий субъект лечебного ритуала. Как и в архаической мифопоэтической модели мира, пространство в лечебных ритуалах белорусов выступает одухотворенным и оживотворенным, объединяет в себе разные по своей семантике единицы. Человек традиции воспринимает себя живущим в мире, состоящем из двух противоположных составляющих - мира реального и мира ирреального, к которому относятся сверхъестественные существа и умершие. Одновременно мир и пространство предстают разделенными на «свое», имеющее положительную оценку, и «чужое», наделенное отрицательным значением. «Семантическая оппозиция “свой чужой” лежит в основе семантизации и оценки пространства” (Левкиевская 2009б: 304). Как отметил М. Элиадэ, «для традиционных обществ очень характерно противопоставление между пространством проживания и неизвестным, неопределенным пространством, которое их окружает. Первое - это “Мир” (точнее, “наш мир”), Космос. Все остальное - это уже не Космос, а нечто подобное “потустороннему миру”, это чужое и хаотичное пространство...» (Элиаде 1994: 27).

При этом единицы природного и культурного ландшафртов в реальной жизненной практике традиционного общества могут наделяться различной, иногда противоположной, символикой. Например, приближенный к поселению водный источник, принадлежащий сфере природы, часто отождествляемой со сфрерой «чужого», в конкретных ситуациях может приобретать сакральный статус и выступать в качестве ритуального центра «своего» пространства (Лобач 2004: 18). Так, в народноветеринарной традиции белорусов широко распространены ритуалы обращения к водным источникам с просьбой избавить коров от мастита и наделить молочностью: «Як не стала малака, нада іціць з рэчкі, браць падойнічак, у што кароўку доіш, падьииціць $\kappa$ вадзе, іиіць нада, штоб ніхто не відаў, такіл иялнейшыли часам, і падходзіш к вадзі гаварыш: "Здраствуй, вадзіиа-иаріиа, Бож'я владычыца, ты уссіл полачы давала, влрні малако этай кароўкі” (ТМКБ 2013: 980). Подобная характерная для традиционной культуры ситуация, при которой происходит 
эмоциональный диалог человека с природой, предполагает принципиально отличное от "современного» отношение человека к окружающему миру, реализуемое не по схеме «Я - Оно», а по схеме «Я - Ты». При таком типе отношения «природа» выступает в качестве партнера по диалогу, а между человеком и окружающей средой выстраиваются индивидуальные, и даже межличностные отношения (Байбурин 1993: 153-154), что позволяет привлекать природные объекты в качестве союзников в лечебных ритуалах.

Рассматривая, каким образом культурное пространство задействовано в лечебных ритуалах, исследователи отмечают, что акциональный код в них сориентирован преимущественно на конкретную пространственно-временную реальность: «в качестве оперативного пространства выступают (с учетом семантической нагрузки) разнообразные локусы именно культурного ландшафрта, начиная с элементов интерьера дома (печь, стол, «красный» угол) и до периферийных объектов освоенного человеком пространства (баня, мельница, корчма)» (Володина $\&$ Лобач 2007: 148). Таким образом, большинство ритуально-магических приемов реализуется в рамках крестьянской усадьбы или поселения, поскольку семантическая амбивалентность пространственных единиц позволяет реализовать цели ритуала, не покидая сфреры «культуры».

Символические приемы народной ветеринарии органично задействуют архетипичную модель мира, что проявляется на вербальном и акциональном уровнях лечебных практик, а также их сочетании. Архетипичная модель мира включает в себя две проекции: четырехчастную горизонтальную и трехчастную вертикальную. При этом в рамках традиционных представлений окружающее пространство выступает как принципиально неоднородное, отрицательно или положительно «заряженное» (Байбурин 1993: 155-156). Во время проведения лечебного ритуала осуществлялись различные процедуры, использующие подобные скрытые возможности тех или иных мест.

Вертикальная проекция (модель) пространства в мифопоэтической картине мира исходит из противопоставления верх - низ. Это противопоставление реализуется в оппозиционных парах небо - земля, земля - подземелье, в которых земля может наделяться позитивной семантикой «своего» верха или, наоборот, отрицательно маркированного низа. Болезнетворные агенты, 
согласно логике лечебного ритуала, локализуются во всех трех уровнях вселенской вертикали, но при изгнании болезни чаще всего апеллируют к ее нижней части. Так, один из распространенных приемов уничтожения болезни - закапывание в землю предметов, связанных или бывших в контакте с больным животным. Например, чтобы избавить лошадь от "вусача» ${ }^{5}$, вдоль ее хребта трижды проводили от уха к хвосту осиновым колом, который затем нужно было вбить глубоко в землю (Wereńko 1896: 177). Подобный прием использовался и в апотропеических ритуалах после отела: «У мяне як первацёлка иялілася, свякроў прышла і гавора: ты местал (последом - А. Ш.) з усхода сониа абнось тры раза. I нешта ж казала, нешта: "Як сониа усходзя красіва, каб так маей карові ніхто не адняў, каб харошая бьла" I тады несьиі эта места закапаць. Не нада, штоб сабакі иягалі яго, закапаеш тал жа ў хлеве» (ТМКБ 2011: 633). Иногда для канализации болезни в нижний уровень вместо земли используются другие сустанции: «З вуглоў мох і труць па спіне скаціны: “Як з вуглоў мох, так і з благаславеннай скаціны хвароба вон”. Мох закапаць у навоз иі зяллю» ${ }^{6}$.

Поляризация же верха и низа, которая наблюдается в заговорных текстах через существование противоположных групп сверхъестественных существ (связанных с небом и связанных с адом) для ритуально-магической лечебной практики мало актуальна. В лечебных ритуалах реализуются представления, когда потусторонний мир или его проявления видятся вокруг, «демоны болезней размещались как внизу, так и наверху, и поэтому “вертикаль” ритуальных действий не определяется строгой однонаправленностью» (Валодзіна 2009: 360). Некоторые представления, при этом, касаются вертикали дома, который выступает одним из ключевых символов культуры, и с которым в той или иной мере соотнесены все важнейшие характеристики жизни человека и его картины мира, в том числе представления о пространстве и времени. Дом, таким образом, репрезентирует трехчленную вертикальную модель с ее серединой и сакрально обозначенными верхом и низом. Так, например, рожь, пересыпанную три раза через отверстие в крыше, давали свиньям как превентивное средство от «заушницы» ${ }^{7}$ (Wereńko 1896: 221). Очень показателен в этой связи ритуал лечения собаки от бешенства, описание которого привел М. Федоровский: «Кедь сабака шалоны пакусае хатняго, то жэб не ашалеў, трэ так 
зрабіиь: Усыюпаць у мешочак з гарнеи аўса, ўзяиь адналу ўлезиі на стрэху і праз колін ўкінуць у хату, а другі жәб уззяу і прэз акно зноў падаў талу, ио на стрэсі $і$ так рабіць тры разы. Потылм высушыць той авёс, злалоць $і$ у тлучь пакусаналу сабациь даць, а сходзі і захадзі слонка на надворку пад капежол» (Federowski 1897: 414).

Горизонтальная же проекция (модель), которая выделяется своей антропоцентричностью, основана на противопоставлении освоенного, «своего» пространства, отделенного от некультурного, неосвоенного, «чужого». «Свое» пространство в традиционной картине мира состоит из ряда концентрических кругов-пространств (дом - двор - деревня), каждое из которых выступает центром следующего. Пункты, принадлежащие к внешнему контуру этих кругов (дверь, порог, окна, крыша, стены; ворота усадьбы, забор; концы деревни, придорожные кресты возле них и т.д.), выступают в народных представлениях воплощением границы между «своим» и враждебным «чужим» миром. Так, значительное количество апотропеических манипуляций проводится именно в таких "пограничных» точках: «Вясной як у поле выганяеш, свянионая вярба калі ёсь, пасцёбаць. Ножык, пад парог ложыш ножык» (ПЭЗ 2011: 292); чтобы уравновесить количество молока двух кров одного хозяина, если одна корова дает очень мало молока, а вторая слишком много, белорусы Витебщины делали отверстие в стене хлева и наливали туда молоко «лучшей» коровы, заткнув потом отверстие шерстью коровы с меньшей удойностью, заколачивали туда осиновый кол (Никифоровский 1897: 152); в отверстие в стене хлева или на дверную пятку клали шерсть больного животного, чтобы избавить его от червей в ране (Wereńko 1896: 225); и т.д. Для того чтобы избавить деревню от эпизоотии, ритуальные действия исполнялись в пограничных локусах деревни: «Разжыгалі кастры падчас палорку жьвёль у пачатку дзярэўні, у каниьь i na бakax» ${ }^{8}$.

Горизонтальная проекция модели мира состоит из четырех основных сегментов пространства, которые соотносятся с географическими сторонами света. Как отмечает В. Лобач, эти четыре направления наделяются в народном сознании «разными энергетическими потенциями» (Лобач 2003: 29). Так, наибольшим напряжением выделяется линия, связующая Восток (Усход) и Запад (Захад), которые воспринимаются как места «рожде- 
ния» и «смерти» солнца. Адресация заговорного текста или другого лечебного ритуала "на захад сонца» призвана, таким образом, канализировать болезнь в данном пространственном направлении, которое ассоциируется в мифологической картине мира с темнотой и смертью, а также считается пограничным локусом - рубежом между днем и ночью, человеческим и инфернальным мирами.

Восток, наоборот, выступает в народных представлениях пространством, ассоциируемым с рождением, жизнью, светом и божественной сферой. Поэтому обращение к Востоку в лечебном ритуале имеет целью «не удаление недуга в обозначенном направлении (как в случае с Западом), но его полное уничтожение при помощи сверхъестественных существ и сакральных стихий» (Валодзіна 2009: 362).

Особенного внимания в контексте лечебных ритуалов заслуживают локусы, воплощающие в себе идею чужого. Амбивалентность как важнейшая характеристика пространства в случае с локусами сферы чужого проявляется в том, что они выступают в ритуальной практике не только как мир болезней, инфернальных существ и область девиаций, но и как место, обращение к которым в определенных случаях может играть определяющую роль в успешном результате лечения. Так, в ряде ритуалов кладбище как символическое воплощение потустороннего мира, опасного, враждебного и одновременно способствующего, поскольку оно включает в свою структуру мир предков и опекунов, выступает источником сверхъестественных ресурсов, необходимых для проведения определенных лечебных ритуалов (Валодзіна 2009: 362-363). Например: «А як не погуляе (не может забеременеть - А. Ш.), у нас ходзили на кладбишче, а тал росце зелень специальная, оно нигде не росиёт, тольки на кладбишче - шышки называециа. Оны и иввтуць. И рвуиь дзевяць штук етых шышочок на кладбишче и их параць и ту воду даюиь пииь [карове]»".

В пределах усадьбы в народноветеринарных магических практиках активно задействована периферийная зона, которая окружает дом и хлев и выделяется погранично-контактными чертами. Прежде всего это касается забора и ворот. Способность выступать медиатором между сферой «своего» и «чужого», которой народное сознание наделяло забор, прослеживается, например, в ритуале избавления коровы от мастита, когда 
молоко больного животного процеживали сквозь сито, а затем выливали в месте, где собственный забор прикасался к соседскому (Wereńko 1896: 222).

Культурные локусы, таким образом, наделяются в лечебной магической практике пограничными и потусторонними характеристиками, что для мифологического сознания означает целостность и полноту, космологическую завершенность непосредственного окружения. Культурное пространство, проявляя свою амбивалентность в лечебных ритуалах, позволяет обращаться к потустороннему миру и контактировать с ним. Человек традиции, благодаря подобным мифопоэтическим представлениям, имеет возможность возобновлять нарушенную вследствие болезни космическую гармонию в рамках собственной усадьбы и ближайшего окружения.

\section{Заключение}

Определяющее значение в хронотопе лечебного ритуала, таким образом, играют "пограничные» точки, будь то время дневного или лунного цикла, определенные дни года, локусы в усадьбе или во вне ее. Данные точки времени и пространства наделялись функциями медиаторов: в переломные моменты времени (например, праздничные дни года) можно было закрепить результат магического воздействия на здоровье скота на более или менее длительный период, низвести болезнь в небытие (например, обращаясь к сакрально маркированным верху или низу, закату или восходу солнца), «перевести» недуг из сферы «своего» в сферу «чужого», восстанавливая и поддерживая тем самым принятый в культуре порядок вещей.

\section{Примечания}

1 Полесский архив Института славяноведения Российской академии наук. Зап. Ф. Б. Успенский в 1983 г. в д. Барбаров Мозырского района Гомельской области.

2 Архив Института искусствоведения, этнографии и фоольклора им. К. Крапивы Национальной академии наук Беларуси. Зап. Г. И. Дмитриева в 1989 г. в д. Веть Быховского района Могилевской области. 
${ }^{3}$ Колючее травянистое растение (репейник, чертополох и т.п.).

4 Архив Института искусствоведения, этнографии и фольклора им. К. Крапивы Национальной академии наук Беларуси. Ф. 23, оп. 4, д. 5. Зап. А. Шрубок в 2014 г. в д. Пересловка Миорского района Витебской области.

5 Заболевание лошадей, которое заключается в появлении желвака на хребте (Никифоровский 1897: 183).

6 Архив Глубокского городского Дома культуры. Зап. О. Волынец в 2005 г. в д. Королевичи Глубокского района Витебской области.

7 Воспаление околоушной железы у свиней.

8 Архив Института искусствоведения, этнографии и фольклора им. К. Крапивы Национальной академии наук Беларуси. Зап. Т. К. Тяпкова в д. Клястицы Россонского района Витебской области.

9 Полесский архив Института славяноведения Российской академии наук. Зап. Н. П. Антропов в д. Велута Лунинецкого района Брестской области.

\section{Источники}

Архив Глубокского городского Дома культуры.

Архив Института искусствоведения, этнографии и фольклора им. К. Крапивы Национальной академии наук Беларуси.

Полесский архив Института славяноведения Российской академии наук.

\section{Литература}

Байбурин, Альберт 1993. Ритуал в традииионной культуре. Структурно-селантический анализ восточнославянских обрядов. СПб.: Наука.

Берман, Иван 1873. Календарь по народным преданиям, в Воложинском приходе Виленской губернии, Ошмянского уезда. Записки илператарского Русскаго геограббиескаго общества по отделению этнографии. Т. 5. СПб: тип. Майкова, сс. 3-43.

Булгаковский, Дмитрий Г. 1890. Пинчуки. Этнографический сборник. Песни, загадки, пословицы, обряды, приметы, предрассудки, 
поверья, суеверья и местный словарь. Собрал въ Пинском уезде Минской губернии Д. Г. Булгаковский. Записки Илператорского Русского географбического общества по отделению этнографбии. T. XIII, Вып. 3. СПб: В. Безобразова и Комп.

Валодзіна, Таццяна 2009. Цела чалавека. Слова, міфб, рылтуал. Мінск: Тәхналогія.

Володина, Татьяна \& Лобач, Владимир 2007. Пространственные характеристики ритуальных практик в народной медицине белорусов. Acta Neophilologia IX. Olsztyn: Wyd-wo Uniwersytetu Warminsko-Mazurskiego, cc. 143-153.

Дмитриев, Михаил А. 1869. Собрание песен, сказок, обрядов и обычаев крестьян северо-западнаго края. Вильна: Типография А. Г. Сыркина.

Добровольский, Владимир Н. 1914. Слоленский областной словарь. Смоленск: Типография П. А. Силина.

Federowski, Michał 1897. Lud Białoruski na Rusi Litowskiej. Materyały do etnografii słowiańskiej zgromadzone w latach 1877-1891. T. 1, Wiara, wierzenia i przesady ludu z okolic Wołkowyska, Słonima, Lidy i Sokółki. Kraków: Nakładem Akademii Umiejętności.

Журавлев, Анатолий Ф. 1994. Домашний скот в поверьях и магии восточных славян. Этнографические и этнолингвистические очерки. Москва: Индрик.

Крачковский, Юлиан 1869. Очерки быта западно-русскаго крестьянина. Виленский сборник. Вильна: Типография А. Г. Сыркина, cc. $160-210$.

Левкиевская, Елена Е. 2009а. Полдень. Славянские древности. Этнолингвистический словарь. Т. 4. Москва: Международные отношения, сс. 131-133.

Левкиевская, Елена Е. 2009б. Пространство. Славянские древности. Этнолингвистический словарь. Т. 4. Москва: Международные отношения, сс. 304-308.

Лобач, Уладзімір 2003. Уяўленні аб прасторы і часе у традыцыйнылм светапоглядзе беларусаў (па этнаграфбіных і фбальклорных матэрыялах XIX - nач. XX cm.). Дыс. канд. гіст. Навук.; Мінск: Нац. акад. навук Беларусі. Ін-т мастацтвазнаўства, этнаграфіi і фальклору імя К. Крапівы 
Лобач, Уладзімір А. 2004. Элементы культурнай прасторы ў сістэме народнай медыцыны Лепельшчыны. Лепельскія чытанні. Лепельскія чытанні. Мат-лы навук.-практычн. канф. Лепель, 12-13 кастр. 2004 г. Леп. раён. краязн. музей; уклад. А. У. Стэльмах. Лепель, сс. 18-22.

Никифоровский, Николай Я. 1897. Простонароднье приметы и поверья, суеверные обряды и обычаи, легендарные сказания о лицах и местах. Витебск: Губернская типо-литография.

Полесские заговоры 2003 = Полесские заговоры: В записях 19701990 г2. Сост., подготовка текстов и коммент. Т. А. Агапкиной, Е. Е. Левкиевской, А. Л. Топоркова. Москва: Индрик.

ПЭЗ 2011 = Полацкі этнаграфбічны зборнік. Вып. 2: Народная проза беларусаў Падзвіння. У 2 ч. Ч. 2. Уклад. У. А. Лобач. Наваполацк: ПДУ.

Пяткевіч, Часлаў 2004. Рэчыцкае Палессе. Мінск: Беларускі кнігазбор.

Раденкович, Любинко 2005. Опасное время в народных представлениях славян. Balcanica. Годишњак Балканолошког института 35. Beograd: Čigoja štampa, cc. 71-90.

Романов, Евдоким Р. 1891. Белорусский сборник. Вып. 5: Заговоры, апокрифы, духовные стихи. Витебск: Типография Г. А. Малкина.

Романов, Евдоким Р. 1911. Материалы по этнографби Гродненской губернии. Вып. 1. Вильна: Издание Управления Виленского учебного округа.

Романов, Евдоким Р. 1912. Белорусский сборник. Вып. 8: Быт белоруса. Вильна: Типография А.Г. Сыркина.

Толстая, Светлана М. 1995. Время. Славянские древности. Этнолингвистический словарь. Т. 1. Москва: Международные отношения, cс. $448-452$.

ТМКБ 2011 = Традыцыйная мастацкая культура беларусаў. Т. 5 . Цәнтральная Беларусь. У 2 кн. Кн. 2. А. М. Боганева (і інш.); ідәя і агул. рэдагаванне Т.Б. Варфаламеевай. Мінск: Вышэйшая школа

ТМКБ 2013 = Традыцыйная мастацкая культура беларусаў. Т. 6 . Гомельскае Палессе і Падняпроўе. А. М. Боганева (і інш.); ідәя і агул. рэдагаванне Т. Б. Варфаламеевай. Мінск: Вышәйшая школа. 
Шейн, Павел В. 1902. Материаль для изучения быта и языка русского населения Северо-Западного края. Т. 3: Описание жилища, одежды, пищи, занятий; препровождение времени, игры, верования, обычное право; чародейство, колдовство, знахарство, лечение болезней, средства от напастей, поверья, суеверья, приметы и т.д. СПб.: Императорская Академия наук.

Шрубок, Аляксандра 2015. Першы выган жывёлы ў поле: арэальная характарыстыка і семантыка. Беларускі фбальклор: матэрыялы i даследаванні 2. Мінск: Беларуская навука, сс. 171-216.

Wereńko, Franciszek 1896. Przyczynek do lecznictwa ludowego. Materiaty antropologiczno-archeologiczne i etnograficzne. T. 1. Kraków: Akademia Umiejętności, cc. 99-229.

Элиаде, Мирча 1994. Священное и мирское. М.: Изд-во МГУ.

\section{Summary}

\section{Healing Ritual's Chronotope Examplified by Belarusian Folk Veterenary Practices}

\section{Aleksandra Shrubok}

Keywords: chronotope, folk veterinary, mythopoetic beliefs, ritual

The paper analyses spacial and temporal peculiarities of Belarusian ritual practices aimed at protecting and healing the livestock.

The fact that some sacred spacial and temporal items are emphasized and endowed with semiotic and cultural functions is based on traditional mythopoetic beliefs. "Borderline" points are the most significant elements in the chronotope of a healing ritual. According to popular belief they play the role of mediators. While preventive measures that were synchronized with the calendar holidays were meant to enforce and prolong the magical impact on the health of the livestock, occasional rituals that were synchronized with sunrise and sunset and the ones that involved sacred loci aimed at transferring the illness from the "insider" to "outsider" sphere in order to restore and maintain cultural conventions. 


\section{МИССИЯ ВЫПОЛНИМА Перспективы изучения фольклора}

http://www.folklore.ee/rl/pubte/ee/sator/sator19/

ISSN 1736-0323

ISBN 978-9949-586-60-8

DOI: $10.7592 /$ Sator.2018.19

Тарту 2018

Редакторы-составители выпуска:

Маре Кыйва \& Татьяна Володина

Редактор серии: Маре Кыйва

Фото: Яак Кикас, 2018 «Осень в Тарту»

Оформление обложки: Лииса Весик

Верстка \& HTML: Диана Кахре

Печатное издание: МИССИЯ ВЫПОЛНИМА:

Перспективы изучения фольклора. SATOR 19. Тарту 2018

Публикация книги осуществлена совместно Эстонским литературным музеем и Центром исследований белорусской культуры, языка и лит ерат уры Националь ной акад емии наук Б еларус и, п ри поддержке Министерства образования и науки Эстонии (IUT 22-5), Фонда регионального развития ЕС (ТK 145, Центр компетенции по Эстонским исследованиям); при поддержке проекта, финансируемого Министерством иностранных дел Эстонии из бюджета по сотрудничеству и развитию, Эстонской Академией Наук и Национальной академии наук Беларуси.

Оформление электронного издания осуществлено при поддержке проекта ЕККМ14-344 “Расширение областей применения и представление эстонского языка, культуры и фольклора в электронных информационных средствах".

() Эстонский литературный музей

(c) Авторы

(с) Яак Кикас 